\title{
Degradative succession of the insects in small rodents in subtropical systems
}

\author{
Sucessão degradativa de insetos em carcaças de pequenos roedores em sistemas subtropicais \\ Sucesión degradante de insectos en pequeñas canales de roedores en sistemas subtropicales
}

Received: 12/09/2021 | Reviewed: 12/13/2021 | Accept: 12/17/2021| Published: 01/02/2022

Bruna da Silva

ORCID: https://orcid.org/0000-0002-0012-0999 Universidade Comunitária da Região de Chapecó, Brazil E-mail: runa_silva@unochapeco.edu.br

Suéle Santolin

ORCID: https://orcid.org/0000-0003-1637-1896 Universidade Comunitária da Região de Chapecó, Brazil

E-mail: suelesantolin@hotmail.com

Renan de Souza Rezende

ORCID: https://orcid.org/0000-0002-4129-0863

Universidade Comunitária da Região de Chapecó, Brazil E-mail: renan.rezende@unochapeco.edu.br

\begin{abstract}
We evaluated the insect succession in small rodent carcasses on the soil extracts (surface vs. buried) in two areas (riparian vs. agricultural) and two seasonal periods (spring vs. summer). Daily, the rodent carcasses were weighed and the insects present were collected in them for counting and family level identification. We also measured the air and soil temperature daily, in addition to the physical and chemical characteristics of the soil. The total of 11,059 individuals from 28 taxa was collected. The most abundant taxa were Calliphoridae (70\%), Formicidae (20\%), Muscidae (2\%), and Sarcophagidae (2\%). Insect richness was higher in spring in riparian vegetation areas; however, decomposition and insect abundance were greater in spring in agricultural areas by the high temperature measured. Vespidae, Sarcophagidae, Muscidae, and Calliphoridae decreased over time with abundance peaks respectively at 3, 7, 7 , and 8 days in riparian vegetation areas. Calliphoridae decreased abundance over time with a peak at five days, but Armadillidiidae increased with peak at 6-9 days in agricultural areas. Decay and insect abundance was high in agricultural areas, mainly on the soil surface. Insect richness was high in riparian vegetation areas, especially on the soil surface. Only the superficial layers of soil presented taxon indicators and all decreased over time with abundance peaks of Calliphoridae, Sarcophagidae, and Muscidae at 5-8, 7, and 7 days, respectively. This abundance peak of insect families help to understand the degradative succession of the insect community in small rodents in subtropical systems of the neotropical region.
\end{abstract}

Keywords: Forensic entomology; Carcass decomposition; Insect families; Mus musculus.

\section{Resumo}

Avaliamos a sucessão de insetos em carcaças de pequenos roedores no solo (superfície vs. enterrado) em duas áreas (riparia vs. agrícola) e dois períodos (primavera vs. verão). Diariamente, as carcaças foram pesadas e os insetos coletados para contagem e identificação em nível familiar. Também medimos diariamente a temperatura do ar e solo, e características físic0-químicas do solo. Foram coletados 11.059 indivíduos de 28 táxons. Os táxons mais abundantes foram Calliphoridae (70\%), Formicidae (20\%), Muscidae (2\%) e Sarcophagidae (2\%). A riqueza de insetos foi maior na primavera das áreas de vegetação riparia, no entanto, a decomposição e a abundância de insetos foi maior na primavera em áreas agrícolas. Vespidae, Sarcophagidae, Muscidae e Calliphoridae diminuiu com o tempo, com picos de abundância respectivamente em 3, 7, 7 e 8 dias nas áreas de vegetação riparia. Caliphoridae diminuiu a abundância ao longo do tempo com pico em 5 dias, mas Armadillidiidae aumentou, com pico em 6-9 dias em áreas agrícolas. A decomposição e abundância de insetos foram maiores nas áreas agrícolas, principalmente na superfície do solo. A riqueza de insetos foi maior nas áreas de vegetação riparia, especialmente na superfície do solo. Apenas as camadas superficiais do solo apresentaram indicadores de táxons e todas diminuíram ao longo do tempo com picos de abundância de Calliphoridae, Sarcophagidae e Muscidae respectivamente em 5-8, 7 e 7 dias. Pico de abundância de famílias de insetos podem servir como base de dados para investigação e ajudar a determinar os intervalos Post Mortem em sistemas subtropicais do Neotropical.

Palavras-chave: Entomologia forense; Decomposição de carcaça; Famílias de insetos; Mus musculus.

\section{Resumen}

Evaluamos la sucesión de insectos en pequeños cadáveres de roedores en el suelo (superficie vs. enterrados) en dos áreas (ribereña vs. agrícola) y dos períodos (primavera vs. verano). Diariamente, se pesaron los cadáveres y se 
recolectaron los insectos para el recuento e identificación a nivel del hogar. También medimos diariamente la temperatura del aire y del suelo, y las características físico-químicas del suelo. Se recolectaron 11.059 individuos de 28 taxones. Los taxones más abundantes fueron Calliphoridae (70\%), Formicidae (20\%), Muscidae (2\%) y Sarcophagidae (2\%). La riqueza de insectos fue mayor en primavera en áreas de vegetación ribereña, sin embargo, la descomposición y abundancia de insectos fue mayor en primavera en áreas agrícolas. Vespidae, Sarcophagidae, Muscidae y Calliphoridae disminuyeron con el tiempo, con picos de abundancia respectivamente a los 3, 7, 7 y 8 días en áreas de vegetación ribereña. Caliphoridae disminuyó en abundancia con el tiempo con un pico a los 5 días, pero Armadillidiidae aumentó, con un pico a los 6-9 días en áreas agrícolas. La descomposición y la abundancia de insectos fueron mayores en las áreas agrícolas, especialmente en la superficie del suelo. La riqueza de insectos fue mayor en las áreas de vegetación ribereña, especialmente en la superficie del suelo. Solo las capas superiores del suelo mostraron indicadores de taxones y todos disminuyeron con el tiempo con picos de abundancia de Calliphoridae, Sarcophagidae y Muscidae respectivamente en 5-8, 7 y 7 días. Las abundancias máximas de familias de insectos pueden servir como base de datos para la investigación y ayudar a determinar los intervalos post mortem en sistemas neotropicales subtropicales.

Palabras clave: Entomología forense; Descomposición de la canal; Familias de insectos; Mus musculus.

\section{Introduction}

Decomposition is a continuous degradation process that releases $\mathrm{CO}_{2}$ and energy (Bornemissza, 1957; Higley \& Huntington, 2009; Medeiros et al., 2015; Rezende et al., 2021) that starts at the death of the organism and end when the carcass is reduced to the skeleton (Probst et al., 2020; von Hoermann et al., 2021; Wolff et al., 2001). In addition, another important process is pedogenesis, which depends on animals that mix organic matter with mineral components in the soil (Moskowitz et al., 2015; Oliveira-Costa, 2013). Both processes, decomposition and pedogenesis, are essential for the ecosystem maintenance (Bornemissza, 1957; Moskowitz et al., 2015) as they allow nutrients and minerals to be reused in the food chain (Alvim et al., 2015; Rezende et al., 2019; Rezende et al., 2021). Also, animal carcass is important for the reproduction of some insects, as Nicrophorus concolor (Coleoptera: Silphidae) (Ito, 2021). Therefore, insect colonization in carcasses decomposing with abiotic factors influence (e.g. temperature and moisture) and carcass conditions (e.g., completeness, toxicology, and pathology) may determine the decomposition rates in an ecosystem (Andrade-Herrera et al., 2020; Jales et al., 2020; Moretti et al., 2008; Von Hoermann et al., 2021).

Insects constitute the most abundant and diverse group, and they are found in almost all terrestrial habitats and aquatic environment, except in salt water (Haskell et al., 2008). Insects may travel to distances of three to five kilometers for locating a suitable habitat for laying their eggs (Higley \& Huntington, 2009). In this sense, insects are usually the first to find a decomposing body. Therefore, through the insect community structure, it is possible to determine the Post Mortem Interval (PMI) and the place of death, as the succession of species on carcasses is also considered a serial replacement class (Haskell et al., 2008; Probst et al., 2020). The degradative succession process may occur on a relatively short time scale; however, succession patterns may vary widely and according to the distinctiveness of the fauna in each local region (Oliveira-Costa, 2013). In this way, the study of the degradation succession process must take into account the local patterns of visiting cadaveric insect fauna ( $\mathrm{Na} \& \mathrm{Pt}, 2013$; Wang et al., 2021). Thereby, this studies are important to understand the degrading succession process and provide subsidies to nutrient cycling from these carcasses (Haskell et al., 2008).

Small rodents can be abundant in subtropical systems and have important ecological functions, such as invertebrate control and seed consumption (Rabinowitz \& Nottingham, 1989; Terborgh et al., 1993). Small rodents may be a frequent source to dead organic matter of animal origin in systems where they are abundant (Maestri et al., 2014; Terborgh et al., 1993), due to the fast life cycle compared to other mammals (Feng \& Himsworth, 2014). In the subtropical region of the Neotropics, native genre such as Akodon, Bibimys, and Brucepattersonius are abundant (Maestri et al., 2014). On the other hand, nonnative rodents are common and abundant as the genus Mus. The genus Mus was introduced in Brazil in the European colonization, and was the main representative the species Mus musculus that can inhabit both urban and rural areas (Feng \& 
Himsworth, 2014). However, despite many studies in the tropical region (Cruz \& Vasconcelos, 2006; Jales et al., 2020; Oliveira-Costa, 2013; Pujol-Luz et al., 2006), few studies were carried out in the Neotropical subtropical region on the survey of cadaveric fauna (Trivia \& Carvalho, 2018).

Studies shows a high insect community variation, mainly by habitat differences (Parry et al., 2016), food availability (T. D. C. Moretti et al., 2008), insect community structure (Tembe \& Mukaratirwa, 2021), and temporal changes (Richards et al., 2009). Studies in other regions have shown that Diptera and Coleoptera account for $60 \%$ of the fauna associated with decaying carcasses, and Chrysomya sp. are an important gender of scavenger fauna (Haskell et al., 2008; Oliveira-Costa, 2013; Tembe \& Mukaratirwa, 2021). According to Moretti et al. (2008), a higher diversity of arthropods has been found in cadaveric fauna, and Chrysomya megacephala (Fabricius, 1974) may be an important specie of scavenger fauna in southern Brazil (Carvalho \& Mello-Patiu, 2008; Trivia \& Carvalho, 2018). Also Moretti et al. (2008) show the presence of other necrophagous families that are of forensic interest, such as Sarcophagidae and Drosophilidae. In this way, our objectives were the following: i) compare the richness and abundance of insects throughout the rodent carcasses decomposition, as well as the decomposition process itself by repeated-measures ANOVA, using time in days as a random factor; and ii) evaluate which insects were temporal indicators, positively or negatively, along the degradative colonization process through Threshold Indicator Taxa Analysis between areas (riparian vs. agricultural), periods (spring vs. summer), and soil depths (depth vs. surface).

\section{Methodology}

\subsection{Study area}

The study was carried out in a riparian vegetation area (26 54'51'S and 52\%41'03”W) and an adjacent agricultural area $\left(26^{\circ} 54^{\prime} 46^{\prime \prime} \mathrm{S}\right.$ and $52^{\circ} 41^{\prime} 08^{\prime \prime} \mathrm{W}$ ) in spring (October 2020) and summer (January 2021) at both locations in the West (Coronel Freitas City) of Santa Catarina State, Brazil. The agricultural area shows culture rotation throughout the year by pasture, oat, and corn in the Atlantic Forest biome. The climate is of Cfa type with an average annual temperature range of 17 to $20^{\circ} \mathrm{C}$ and precipitation of 1900 to $2200 \mathrm{~mm}$. The predominant soil is Red Latosol, with a soft undulated relief, with a very clayey texture, which may vary with LitholicNeosol and Haplic Cambisol.

\subsection{Environmental characteristics}

The chemical and physical properties of the soil were collected at the same points where litter bags were incubated. The samples were collected at depths from 0.0 to $10 \mathrm{~cm}$ for the chemical and physical characteristics of the soil. Air and soil temperatures were measured daily using a thermometer and the soil moisture by drying at $80^{\circ} \mathrm{C}$ to constant weight ([initial weight - final weight]/initial weight). Rainfall was measured by a portable rain gauge during the experiment period. The chemical characteristics of the soil were analyzed by the Soil Analysis Laboratory of the Agricultural Research and Rural Extension Company of Santa Catarina - EPAGRI in Chapecó/SC. Clay was determined by densiometry, pH water and SMP by potentiometry, P by Mehlich-1/colorometry, K by Mehlich-1/flame photometer, MO by spectroscopy, and Al, Ca, and Mg by $\mathrm{KCl}$ /atomic absorption spectrophotometry. The characterization of the soils was performed according to the methodology proposed by Tedesco et al. (1995).

\subsection{Sampling unit}

The insect community was collected from rodent carcasses of the Mus musculus species (Schwartz; Schwartz, 1943), weighing between $27.33 \mathrm{~g}$ and $35.70 \mathrm{~g}$ (mean of $31.11 \mathrm{~g}$ ). All rodents were donated by the Unochapecó Bioterism Center (Ethics Committee - CEUA no. 010/20) and submitted to euthanasia by cervical dislocation. At each area, rodent carcasses were then placed in soil covered by cages $(37 \mathrm{~cm} \times 27 \mathrm{~cm} ; 3 \mathrm{~cm}$ mesh) and some weight was providing above each cage to keep cages 
constant and protect carcasses from the attack of large animals $10 \mathrm{~m}$ away from each other. Insects attracted to rodent carcasses were collected daily from 13:00 to 14:00 hour. The collected insects were preserved in 70\% ethanol after washing them in tap water, and then transferred in labeled tubes to the laboratory.

\subsection{Morphological identification}

The collected insects were examined under stereomicroscope (Zeiss Stemi 305 binocular) and identified following the morphological identification key of Byrd and Castner (2001) and Carvalho and Mello-Patiu (2008). A part of the collected insects was preserved and deposited in the ecological entomology laboratory of Community University of the Chapecó Region - Unochapecó.

\subsection{Experiments}

In the experiment I, we tested the degradative succession between periods (spring vs. summer) and areas (riparian vs. agricultural). The rodent carcasses were used at six points on the surface of riparian vegetation areas and in six points on the surface of agricultural areas over two periods (spring vs. summer). The sampling effort totaled 24 rodent carcasses (6 points $\mathrm{x}$ 2 areas $\mathrm{x} 2$ periods $=24$ carcasses - half male and half female).

In the experiment II, we tested the degradative succession between soil layers - surface vs. buried only in riparian vegetation areas. Rodent carcasses were used at three points, with three carcasses placed on the soil surface, three carcasses buried in the soil of riparian vegetation areas, three carcasses placed on the soil surface, and three carcasses buried in the soil of agricultural areas in two periods (spring vs. summer). The sampling effort totaled 24 rodent carcasses ( 3 points $\mathrm{x} 2$ areas $\mathrm{x} 2$ periods $\mathrm{x} 2$ depths $=24$ carcasses - half male and half female).

\subsection{Data analysis}

The normality of the data (function "ks.test" from the "dgof" package for R) was assessed with the KolmogorovSmirnov test while the homogeneity of variances was assessed with Levene's test and the data were transformed when necessary $(\log 10(\mathrm{x}+1))$. In the experiment I, seven Repeated-Measure ANOVA models were created (RM-ANOVA; "aov" + Error (repeated measure factor = days) function from "stats" package for R) to test i) the remaining mass of rodent carcasses by ([initial weight - final weight] * 100 / initial weight), ii) insect richness, iii) insect abundance, temperature of (iv) air and v) soil), vi) rainfall and vii) soil moisture (response variables) between areas (riparian vs. agricultural), periods (spring vs. summer), and interaction between variables (explanatory variable) (Crawley, 2007). Other seven RM-ANOVA models from experiment II, with the same response variables to test areas (riparian vs. agricultural), soil depth (surface vs. buried), and interaction between variables (explanatory variable) also used days as a random repeat factor (Crawley, 2007). Contrast analysis ("coms" function from the "coms.R" package for R) was used to discriminate among explanatory variables (Crawley, 2007). In this contrast analysis (orthogonal), the explanatory variables were increasingly ordered and tested pairwise with the closest values, sequentially adding values to the model month with no differences and testing with the following, in a stepwise simplification of the model (Crawley, 2007).

Threshold Indicator Taxa Analysis ("titan" function from the "TITAN2" package for R) was used to track the relationship (positive or negative) and check in which period in days the insect community on rodent carcasses are associated across four individual models (riparian vs. agricultural and surface vs. buried) (Baker \& King, 2013). In experiment I, the studied areas (riparian and agricultural) were tested over the days, using the seasonal periods as replicates. In experiment II, the studied soil depths (surface and buried) were tested over the days, using the seasonal periods as replicates. The Threshold Indicator Taxa Analysis is based on Indicator Species Analysis (Dufrêne \& Legendre, 1997) and the Change Point Analysis 
(King \& Richardson, 2003). Based on the frequency of occurrence and relative abundance of the insect community in rodent carcasses, changes were detected in the distribution of species in environmental gradients by Threshold Indicator Taxa Analysis (King et al., 2011). In this way, Threshold Indicator Taxa Analysis highlights the change point based on alterations in mean and variance of response variable, with $\mathrm{z}$ - (negative responders, or decliners) and $\mathrm{z}+$ (positive responders, or increasers) of the species being associated with the lowest and highest values of the environmental gradient analyzed, respectively (Baker $\&$ King, 2010). These changes in the distribution of species from Threshold Indicator Taxa Analysis were detected in space or over time, and associate individual species with different environmental and temporal scores (King et al., 2011). In the Threshold Indicator Taxa Analysis, only species with a frequency of at least 3 were considered. Also, for the Threshold Indicator Taxa Analysis, the significance was set at $\mathrm{p}$ (IndVal) $\leq 0.05$, and purity and reliability set at $\geq 0.70$ were considered (Baker \& King, 2010).

\section{Results}

\subsection{Environmental characteristics}

In experiment I, the air temperature was significantly high in riparian vegetation areas (Repeated Measure ANOVA; $\left.\mathrm{F}_{(1,204)}=8.77 ; \mathrm{p}=0.003\right)$, while the temperature of soil and rainfall were significantly high in the agricultural area $(\mathrm{RM}$ ANOVA; $\left.F_{(1,204)}=50.21 ; \mathrm{p}<0.001\right)$. Both temperatures (air and soil) were significantly high in spring $\left(\mathrm{RM} A N O V A ; F_{(1,204)}=\right.$ $62.39 ; \mathrm{p}<0.001 ; \mathrm{F}_{(1,204)}=20.72 ; \mathrm{p}<0.001$, respectively). On the other hand, rainfall was significantly high in summer $(\mathrm{RM}$ ANOVA; $\left.\mathrm{F}_{(1,204)}=5.51 \mathrm{E}+29 ; \mathrm{p}<0.001\right)$. Soil moisture changed significantly only in the interaction between areas and seasonal periods ( $\mathrm{RM}$ ANOVA; $\mathrm{F}_{(1,204)}=3.99 ; \mathrm{p}=0.047$ ), with the high values in the summer of the agricultural areas compared to the spring of the agricultural areas.

In experiment II, air temperature was significantly high in riparian vegetation areas $\left(\mathrm{RM}\right.$ ANOVA; $\mathrm{F}_{(1,214)}=11.57 ; \mathrm{p}=$ $0.001)$, while the temperature of soil and rainfall were significantly high in the agricultural area $\left(\mathrm{RM} A N O V A ; \mathrm{F}_{(1,214)}=56.22\right.$; $\mathrm{p}<0.001)$. The temperature of the soil was significantly high at surface compared to deep layers $\left(\mathrm{RM} A N O V A ; F_{(1,214)}=7.52 ;\right.$ $\mathrm{p}=0.007)$. Soil moisture was significantly high in riparian vegetation areas compared to agricultural areas (RM ANOVA; $\left.F_{(1,214)}=5.10 ; p=0.025\right)$. Also, soil moisture significantly changed in the interaction between areas and depth, with high values in deep layers of riparian vegetation areas compared to the superficial soil layers of the agricultural areas (RM ANOVA; $\left.\mathrm{F}_{(1,214)}=25.95 ; \mathrm{p}<0.001\right)$.

Comparing the soil surface characteristics on the two areas, we observe a high values of clay densiometry ( $41 \pm 3.0$ vs.

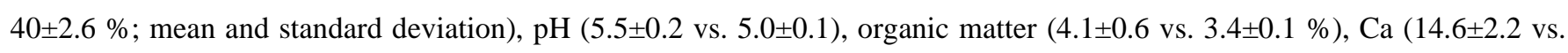
$\left.13.0 \pm 1.1 \mathrm{cmolc} / \mathrm{dm}^{3}\right)$, and cation exchange capacity $\left(22.4 \pm 2.1 \mathrm{vs} .20 .8 \pm 1.5 \mathrm{cmolc} / \mathrm{dm}^{3}\right)$ in riparian vegetation areas compared to agricultural areas, respectively. On the other hand, $\mathrm{P}\left(24.7 \pm 3.7\right.$ vs. $\left.22.3 \pm 4.1 \mathrm{mg} . \mathrm{dm}^{3}\right), \mathrm{K}(345.6 \pm 22.6$ vs. $292.4 \pm 33.6$ mg. $\left.\mathrm{dm}^{3}\right), \mathrm{Al}\left(0.23 \pm 0.1\right.$ vs. $\left.0.20 \pm 0.1 \mathrm{cmolc} / \mathrm{dm}^{3}\right)$, and $\mathrm{Mg}\left(3.8 \pm 0.1 \mathrm{vs} .3 .6 \pm 0.3 \mathrm{cmolc} / \mathrm{dm}^{3}\right)$ show the high values in agricultural areas compared to riparian vegetation areas, respectively. We also found low values of clay densiometry $(31.6 \pm 6.5 \%$; mean and standard deviation), organic matter $(3.4 \pm 1.2 \%)$, Ca $\left(12.6 \pm 1.4 \mathrm{cmolc} / \mathrm{dm}^{3}\right)$ and cation exchange capacity $(20.6 \pm 2.3$ cmolc/ $\mathrm{dm}^{3}$ ) in deep layers of riparian vegetation areas compared to soil surface. On the other hand, the high values of $\mathrm{pH}$ (5.3 \pm 0.4$), \mathrm{P}\left(29.7 \pm 8.5 \mathrm{mg} . \mathrm{dm}^{3}\right), \mathrm{K}\left(334.3 \pm 55.6 \mathrm{mg} . \mathrm{dm}^{3}\right), \mathrm{Al}\left(0.46 \pm 0.5 \mathrm{cmolc} / \mathrm{dm}^{3}\right)$, and $\mathrm{Mg}\left(3.6 \pm 0.6 \mathrm{cmolc} \mathrm{dm}^{3}\right)$ were in deep layers of riparian vegetation areas compared to soil surface.

\subsection{Insect community}

The total of 11,059 individuals from 28 taxa were collected (Table 1). The most abundant taxa were Calliphoridae (70\%), Formicidae (20\%), Muscidae (2\%), and Sarcophagidae (2\%). In total, we found 6,605 individuals (36.6 \pm 108 ind. mean 
and standard deviation) in the riparian vegetation area and 4,454 (24.7 \pm 62 ind.) individuals in the agricultural area. Moreover,

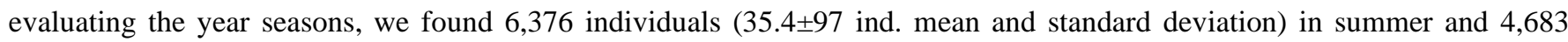
(26.1 \pm 79 ind.) individuals in spring.

Table 1. Occurrence of insects collected on rodent carcasses in riparian vegetation areas and agricultural areas in two periods (spring - spr and summer - sum) of buried (bur) and soil surface (sur) rodent carcasses.

\begin{tabular}{|c|c|c|c|c|c|c|c|c|}
\hline & \multicolumn{2}{|c|}{ riparian } & \multicolumn{2}{|c|}{ agricultural } & \multicolumn{2}{|c|}{ riparian } & \multicolumn{2}{|c|}{ agricultural } \\
\hline & bur & sur & bur & sur & spr & sum & spr & sum \\
\hline \multicolumn{9}{|l|}{ Insecta } \\
\hline Dermaptera & & & & & & & & \\
\hline $\begin{array}{l}\text { Forficulidae } \\
\text { Orthoptera }\end{array}$ & 2 & 0 & 0 & 2 & 0 & 2 & 0 & 2 \\
\hline $\begin{array}{l}\text { Gryllidae } \\
\text { Isopoda }\end{array}$ & 1 & 0 & 0 & 0 & 1 & 0 & 0 & 0 \\
\hline $\begin{array}{l}\text { Armadillidiidae } \\
\text { Hemiptera }\end{array}$ & 2 & 1 & 11 & 12 & 0 & 3 & 0 & 23 \\
\hline $\begin{array}{l}\text { Ectrichodiinae } \\
\text { Hymenoptera }\end{array}$ & 0 & 1 & 0 & 0 & 0 & 1 & 0 & 0 \\
\hline Pompilidae & 2 & 5 & 0 & 0 & 2 & 5 & 0 & 0 \\
\hline Vespidae & 7 & 14 & 0 & 0 & 9 & 12 & 0 & 0 \\
\hline Sphecidae & 2 & 3 & 0 & 0 & 5 & 0 & 0 & 0 \\
\hline $\begin{array}{l}\text { Formicidae } \\
\text { Coleoptera }\end{array}$ & 101 & 1672 & 4 & 1138 & 163 & 1610 & 702 & 440 \\
\hline Cerambycidae & 13 & 11 & 0 & 0 & 24 & 0 & 0 & 0 \\
\hline Cleridae & 5 & 3 & 0 & 6 & 8 & 0 & 0 & 6 \\
\hline Coccinellidae & 0 & 1 & 0 & 0 & 1 & 0 & 0 & 0 \\
\hline Curculionidae & 1 & 0 & 0 & 0 & 1 & 0 & 0 & 0 \\
\hline Chrysomelidae & 0 & 6 & 0 & 4 & 5 & 1 & 0 & 4 \\
\hline Dermestidae & 1 & 0 & 0 & 0 & 0 & 1 & 0 & 0 \\
\hline Glaresidae & 0 & 1 & 0 & 0 & 1 & 0 & 0 & 0 \\
\hline Hydrophilidae & 1 & 0 & 0 & 0 & 1 & 0 & 0 & 0 \\
\hline Leiodidae & 2 & 5 & 0 & 0 & 2 & 5 & 0 & 0 \\
\hline Neriidae & 0 & 1 & 0 & 0 & 1 & 0 & 0 & 0 \\
\hline Nitidulidae & 25 & 3 & 0 & 0 & 26 & 2 & 0 & 0 \\
\hline Noteridae & 13 & 5 & 0 & 1 & 16 & 2 & 0 & 1 \\
\hline Scarabaeidae & 4 & 8 & 2 & 7 & 2 & 10 & 0 & 9 \\
\hline $\begin{array}{l}\text { Staphylinidae } \\
\text { Lepidoptera }\end{array}$ & 0 & 3 & 1 & 12 & 0 & 3 & 0 & 13 \\
\hline $\begin{array}{l}\text { Lycaenidae } \\
\text { Diptera }\end{array}$ & 1 & 0 & 0 & 0 & 1 & 0 & 0 & 0 \\
\hline Calliphoridae & 229 & 2148 & 212 & 5193 & 884 & 1493 & 2777 & 2628 \\
\hline Drosophilidae & 2 & 2 & 0 & 0 & 4 & 0 & 0 & 0 \\
\hline Muscidae & 28 & 50 & 0 & 0 & 20 & 58 & 0 & 0 \\
\hline Sarcophagidae & 14 & 52 & 0 & 0 & 24 & 42 & 0 & 0 \\
\hline Tephritidae & 2 & 1 & 0 & 0 & 3 & 0 & 0 & 0 \\
\hline
\end{tabular}

In experiment I, the remaining masses were high in the spring of riparian vegetation areas compared to the spring of the agricultural area (Table 2a; Figure 1a). The insect richness was high in riparian vegetation areas (Table 2b; Figure 1c), mainly in spring (Table 2b; Figure 1c). On the other hand, the insect abundance was high in agricultural areas (Table 2c; Figure 1e), mainly in summer (Table 2c; Figure 1e). Threshold values over time ranged between 2.5 to 10 (sumz + ) and 1.5 to 7 (sumz -). According to the significance criteria adopted here ( $\mathrm{p} \leq 0.05$, reliability and purity $\geq 0.70$ ), 5 taxa (Vespidae, Sarcophagidae, Muscidae, Calliphoridae, and Armadillidiidae) had a systematic relationship with the time in days. In the riparian vegetation areas, the families Vespidae, Sarcophagidae, Muscidae, and Calliphoridae showed a decrease in abundance to time with respective peaks in 3, 7, 7, and 8 days (Figure $2 \mathrm{a}$ and $2 \mathrm{~b}$ ). In agricultural areas, the family Calliphoridae also showed a decrease in abundance to time with peak in 5 days (Figure $2 \mathrm{c}$ e 2d), butthe family Armadillidiidae showed an 
increase in abundance to time with peak in 6-9 days (Figure 2c e 2d).

Table 2. Result of Repeated Measure ANOVA and Contrast Analysis (Post Hoc) of the remaining mass (a), insect richness (b), and insect abundance (c) in rodent carcasses between areas (riparian vs. agricultural), periods (spring vs. summer), and interactions between factors in Experiment I.

\begin{tabular}{|c|c|c|c|c|c|c|}
\hline & Df & Sum Sq & Mean Sq & F value & $\operatorname{Pr}(>\mathbf{F})$ & Contrast analysis \\
\hline \multicolumn{7}{|c|}{ A. remaining mass } \\
\hline Error $\mathrm{x}$ days & 1 & 135183 & 135183 & & & \\
\hline area & 1 & 516 & 516 & 1.65 & 0.210 & \\
\hline period & 1 & 602 & 602 & 1.92 & 0.167 & \\
\hline area $\mathrm{x}$ period & 1 & 20927 & 20927 & 66.82 & $<0.001$ & agricultural in spring < riparian in spring \\
\hline Residual & 204 & 63887 & 313 & & & \\
\hline \multicolumn{7}{|c|}{ B. insect richness } \\
\hline Error $\mathrm{x}$ days & 1 & 61.1 & 61.1 & & & \\
\hline area & 1 & 40.8 & 40.9 & 20.63 & $<0.001$ & agricultural <riparian \\
\hline period & 1 & 0.0 & 0.0 & 0.01 & 0.927 & \\
\hline area $\mathrm{x}$ period & 1 & 15.5 & 15.5 & 7.84 & 0.006 & agricultural in spring <riparian in spring \\
\hline Residual & 204 & 403.9 & 2.0 & & & \\
\hline \multicolumn{7}{|c|}{ C. insect abundance } \\
\hline Error $\mathrm{x}$ days & 1 & 61.1 & 61.1 & & & \\
\hline area & 1 & 40.8 & 40.9 & 20.63 & $<0.001$ & riparian <agricultural \\
\hline period & 1 & 0.0 & 0.0 & 0.10 & 0.927 & \\
\hline area x period & 1 & 15.5 & 15.5 & 7.84 & 0.006 & agricultural in spring <agricultural in summer \\
\hline Residual & 204 & 403.9 & 2.0 & & & \\
\hline
\end{tabular}

Source: Authors. 
Figure 1. Remaining mass of rodent carcasses ("a" and "b"), insect richness in rodent carcasses ("c" and "d"), and insect abundance in rodent carcasses ("e" and "f") between areas (riparian vs. agricultural) periods (spring vs. summer; experiment I), and soil depths (depth vs. surface; experiment II). The solid lines are the representations of the linear model, while the remnants of the same color are the $95 \%$ confidence intervals for each model.
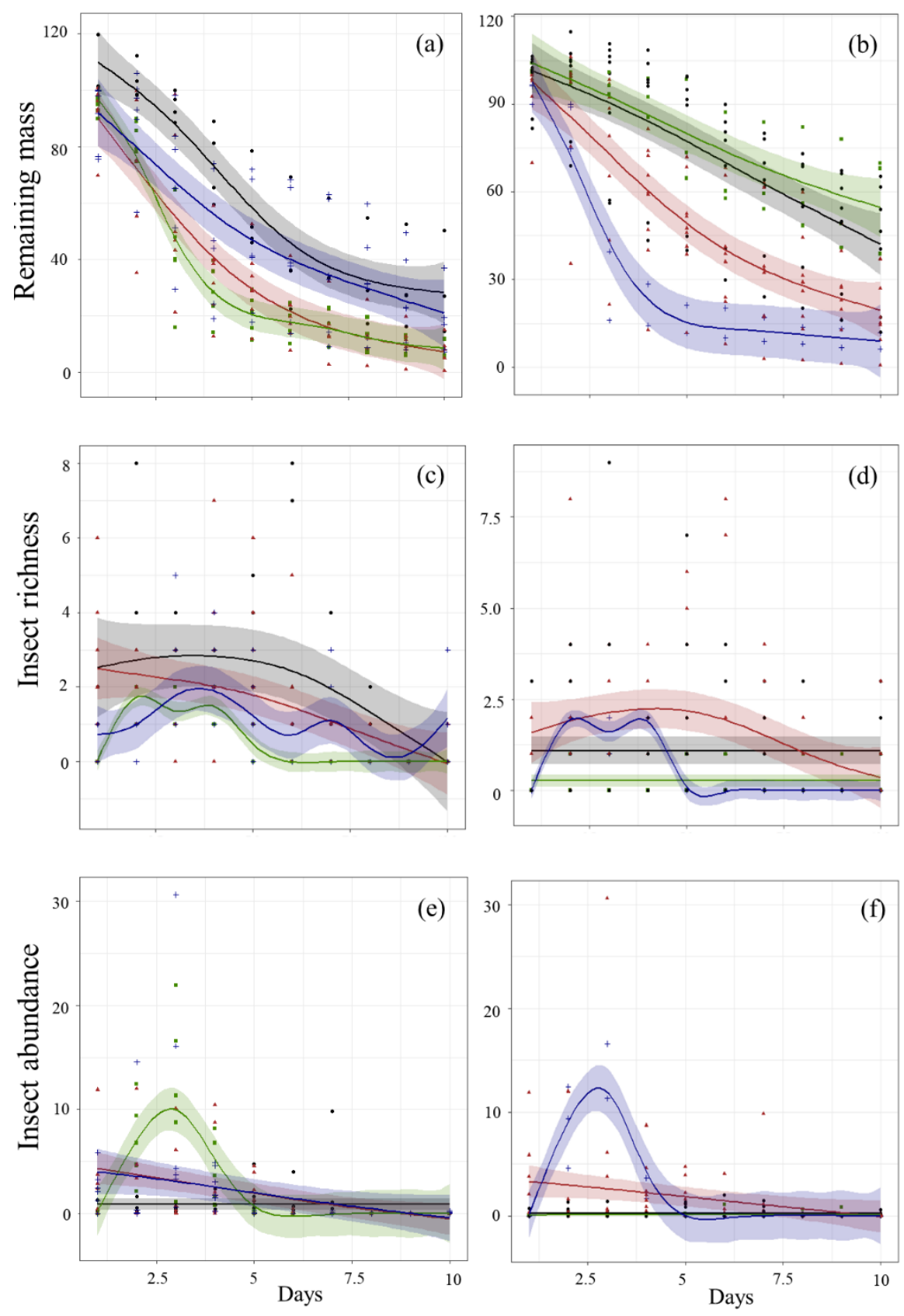

Legend (a, c and e)

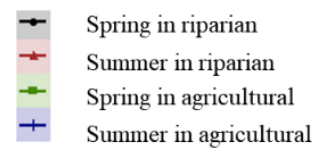

\section{Legend (b, $d$ and $f$ )}

- Soil depth in riparian

- Soil surface in riparian

- Soil depth in agricultural

+ Soil surface in agricultural

Source: Authors. 
Figure 2. Values of the largest indicator $\mathrm{z}$ value in insect abundance in rodent carcasses change points by probability abundance function of the nBoot bootstrapped replicates $(n=500)$ along days from riparian vegetation areas (a), agricultural areas (b), and surface in both areas (c). Taxa names are arranged discretely along the y-axis based on the rank order of the central tendency of the probability abundance function for $\mathrm{z}$ - (dark colors negative, decliners) and z+ (red colors positive, increasers), respectively (a, b, e c). The black symbols represent associated species and sumz-, represented by the black cycle, and sumz + , represented by the white cycle $(b, d$ and $f)$.

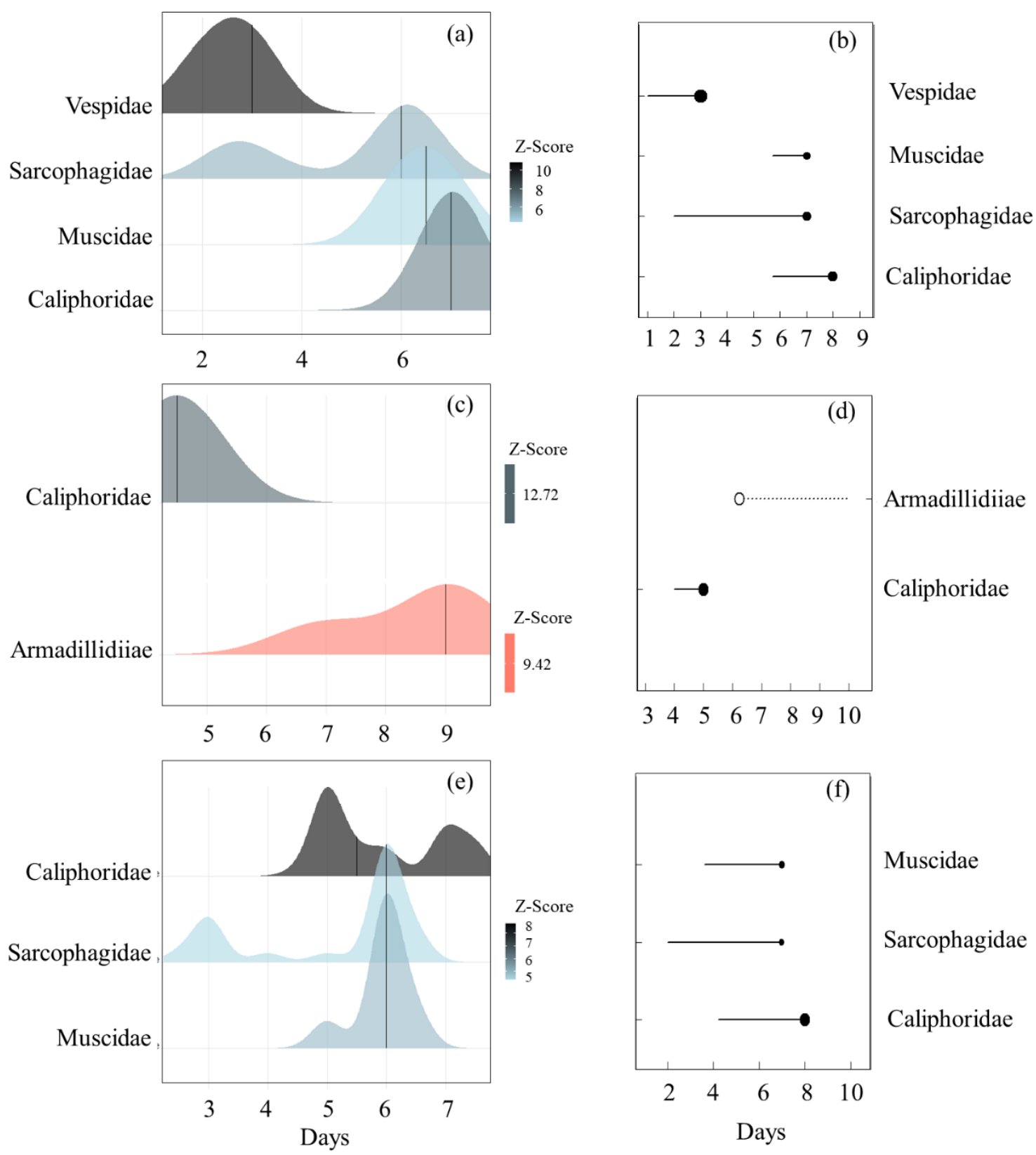

Source: Authors.

In experiment II, the remaining masses were high in agricultural areas compared to the riparian vegetation areas (Table 3a; Figure 1b), mainly in soil surface compared to soil deep layers (Table 3a; Figure 1b). Insect richness was high in the riparian vegetation areas (Table 3b; Figure 1d) and in soil surface compared to soil deep layers (Table 3b; Figure 1d). On the 
other hand, the insect abundance was high in agricultural areas (Table 3c; Figure 1f), also mainly in soil surface compared to soil deep layers (Table 3c; Figure 1f). Threshold values over time ranged between 3 and 10 (sumz +) and between 2 and 7.3 (sumz -). We observe 3 taxa (Sarcophagidae, Muscidae, and Calliphoridae) with a systematic relationship with the time in days. Only the superficial layers of soil presented taxon indicatorsand all decreased with time. The abundance peaks of Calliphoridae, Sarcophagidae, and Muscidae were respectively in 5-8, 7, and 7 days.

Table 3. Result of Repeated Measure ANOVA and Contrast Analysis (Post Hoc) of the remaining mass (a), insect richness (b), and insect abundance (c) in rodent carcasses between areas (riparian vs. agricultural), soil depths (depth vs. surface), and interactions between factors in Experiment II.

\begin{tabular}{lcccccc}
\hline & Df & Sum Sq & Mean Sq & F value & Pr(>F) & Contrast analysis \\
\hline \hline A. remaining mass & & & & & & \\
Error x days & 1 & 112786 & 112786 & & & riparian <agricultural \\
area & 1 & 8435 & 8435 & 23.83 & $<0.001$ & surface < buried \\
soil depths & 1 & 35829 & 35829 & 101.21 & $<0.001$ & surface in riparian <buried in agricultural \\
Local x soil depths & 1 & 1294 & 1294 & 3.66 & 0.057 & agricultural <riparian \\
Residual & 214 & 75754 & 354 & & & buried < surface \\
B. insect richness & & & & & & buried in agricultural <surface in riparian \\
Error x days & 1 & 15.2 & 15.2 & & & \\
area & 1 & 54.5 & 54.5 & 24.07 & $<0.001$ & riparian <agricultural \\
soil depths & 1 & 9.8 & 9.8 & 4.35 & 0.038 & buried <surface \\
area x soil depths & 1 & 0.6 & 0.6 & 0.25 & 0.619 & \\
Residual & 214 & 484.8 & 2.3 & & & \\
C. insect abundance & & & & & & \\
Error x days & 1 & 15.2 & 15.2 & & & \\
area & 1 & 54.5 & 54.5 & 24.07 & $<0.001$ & \\
soil depths & 1 & 9.8 & 9.8 & 4.35 & 0.038 & \\
area x soil depths & 1 & 0.6 & 0.6 & 0.25 & 0.619 & \\
Residual & 214 & 484.8 & 2.3 & & & \\
\hline
\end{tabular}

Source: Authors.

\section{Discussion}

\subsection{Degradative succession between periods}

In experiment I, high decomposition occurred in the seasonal period (spring) and in the area (agricultural) with higher soil temperatures. The higher number of cloudy days and constant rains in summer can reduce the direct sunlight incidence on the soil, decreasing soil temperature compared to spring (Ota et al., 2019). The high soil temperatures in the agricultural area are perhaps due to the lack of coverage in tall plant extracts (De Frenne et al., 2019; Rezende et al., 2017). On the other hand, riparian vegetation areas keep a constant mild microclimate (Quintão et al., 2013; Rezende et al., 2017) compared to agricultural areas. High temperatures may accelerate the ecosystem metabolism by stimulating the decomposing community activity in rodents' carcasses (Navarro et al., 2013; Al-Mekhlafi et al., 2020; Probst et al., 2020). As an example, lower and constant soil temperatures may slow down the metabolic activity and oviposition of detritivorous insects, such as Diptera and Coleoptera, and as calliphorids (Souza \& Linhares, 1997; Pujol-Luz et al., 2006). Insects are pecilothermic, that is, their temperature varies according to the environment. High soil temperatures may also accelerate the immature development (Kutcherov et al., 2019) and, consequently, the food resources consumption (Kotzé et al., 2016), explaining the high decomposition in the warmer area and period. Furthermore, the high abundances observed in the agricultural area may demand greater food resource consumption (Rodríguez \& Liria, 2017; Zeariya \& Kabadaia, 2019), helping to explain the faster decomposition. Finally, there is the increase in invertebrate richness in the riparian vegetation area, possibly because carcasses take a longer time to decay (Moretti et al., 2008) and shows that soil temperatures and the abundance of detritivorous insects are more important in accelerating the decomposition process. 
In experiment I, the families Vespidae, Sarcophagidae, Muscidae, and Calliphoridae in riparian vegetation areas and Calliphoridae in the agricultural area decreased their abundance over time. The families Calliphoridae, Sarcophagidae, and Muscidae have a preference for colonizing soft tissues during the initial stages of decomposition (Cruise et al., 2018; Tembe \& Mukaratirwa, 2021). Furthermore, small carcass decreases the resource available, concentrating the greatest insects' abundances in early stages of decomposition (Al-Mekhlafi et al., 2020; Zeariya \& Kabadaia, 2019). Also, the presence of hymenoptera in rodent carcasses is common, especially species of Vespidae families (Haskell et al., 2008). Vespidae may feed on bodily fluids and dipteran larvae (Moretti \& Ribeiro, 2006), justifying their high abundance in early decomposition stages. Some Vespidae species may chew the tissues of carcass natural cavities (nose, mouth, and anus), looking for liquids or small pieces of meat (Herdina et al., 2016). On the other side, Armadillidiidae showed an increase in abundance over time in agricultural areas, probably to use the carcasses as a refuge against dissection (Haskell et al., 2008; Oliveira-Costa, 2013).

\subsection{Degradative succession between soil layers}

In experiment II, high decomposition occurs in riparian vegetation area, mainly in the superficial layers of the soil, due to differences in moisture. Less vegetation cover increasestemperature variations and decreases soil moisture (De Frenne et al., 2019; Rezende et al., 2017). Lower humidity may make the environment more hostile to specialist organisms, such as detritivorous insects subject to dissection (Sfenthourakis and Hornung, 2018). High moisture in topsoil may accelerate insect colonization compared to lower soil layers. Moreover, richness was high in riparian vegetation areas, especially in superficial soil layers. Soil can act as a barrier to the detritivorous insects, delaying colonization and decreasing richness by reducing decomposition of the buried soil extract eight times compared to the soil surface. On the other hand, insect abundance was high in agricultural areas. Insect abundance may have been influenced by the lower presence of predators. Fewer ants in the carcasses, female of Diptera were able to colonize the available resource more intensively, indicating that the specific insect composition may be important for the decomposition process.

In experiment II, only the superficial layers of the soil showed indicator taxa, all (Calliphoridae, Sarcophagidae, and Muscidae) decreasing abundance with time. Succession studies of cadaveric fauna highlight that species of families Calliphoridae, Sarcophagidae, and Muscidaecan stay longer on carcass, but decreasein abundance with time (Cruise et al., 2018; Haskell et al., 2008; Parry et al., 2016; Tembe \& Mukaratirwa, 2021). They are attracted by the odors that are produced in the early stages of decomposition (Oliveira-Costa, 2013). These peaks also explain the influence of the carcass condition, due to the high humidity (Tembe \& Mukaratirwa, 2021), where rodents rot faster.

\subsection{Drying process of rodent carcasses}

We observed five decomposition stages of Mus musculus: initial decay, putrefaction, black putrefaction, fermentation, and dry decay (Figure 3), as also observed by Moretti et al. (2008). Also, some rodent carcasses in decomposition process may undergo skeletonization or mummification (Figure 4). Mummification is a drying process, dependent on extreme factors of temperature and humidity, which inhibits bacterial activity (Al-Mekhlafi et al., 2020; Tembe \& Mukaratirwa, 2021). As an example, high temperatures and low humidity accelerate the decomposition of rodent carcasses, but cause the mummification of some carcasses (Al-Mekhlafi et al., 2020; Haskell et al., 2008). In the present study, the drying process of some carcasses was observed from the $8^{\text {th }}$ day of summer in riparian vegetation areas by high temperatures. In addition, the attractiveness of flies is not hindered, since they were found in the process of drying the carcasses in this study. 
Figure 3. Decomposition stagesof Mus musculus: (a) initial decay, (b) putrefaction, (c) black putrefaction, (d) fermentation and (e) dry decay.

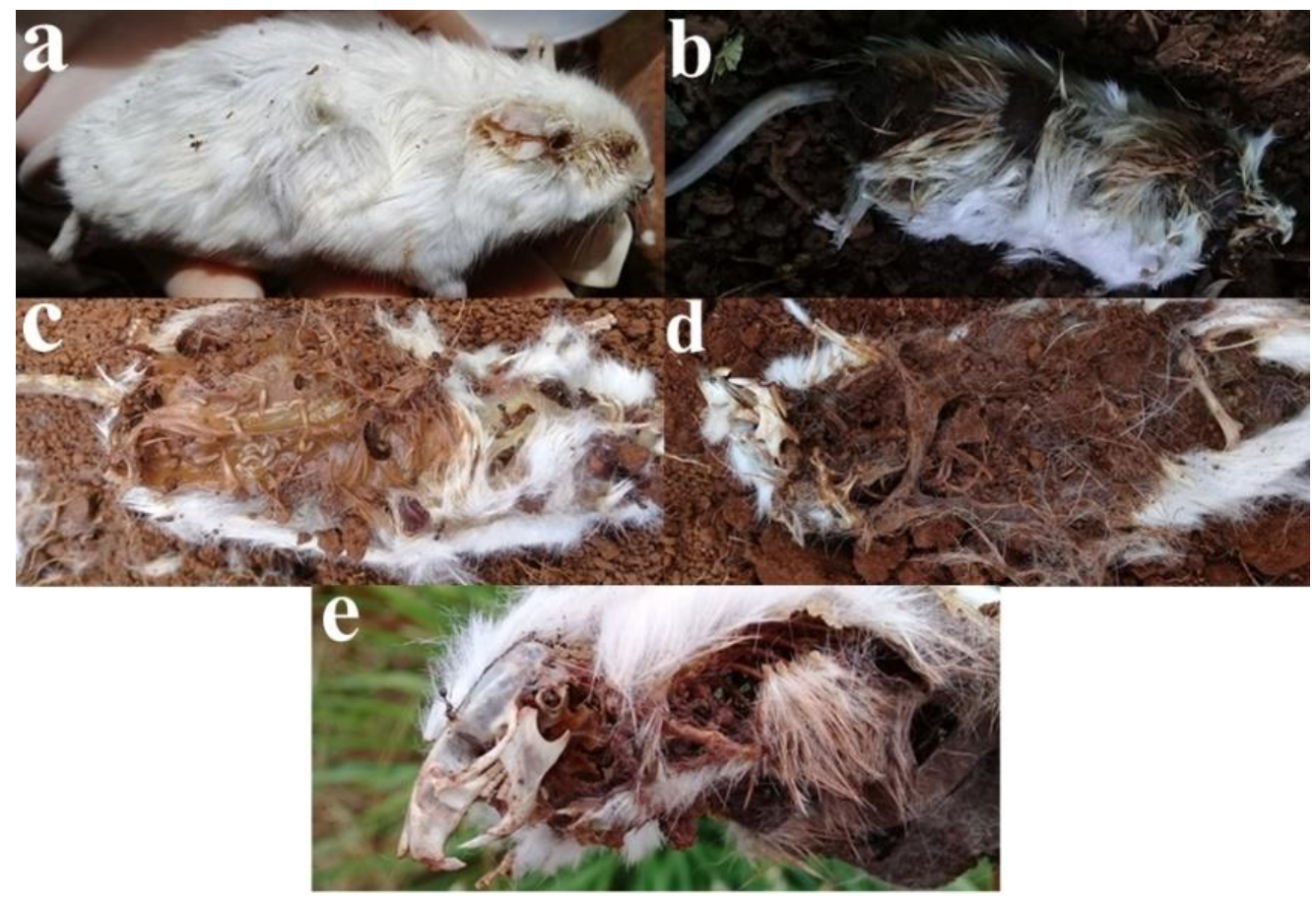

Source: author.

In this way, the drying process of carcasses may then favor the Coleoptera and Formicidae, which colonize the carcasses in the final stages, as they have a preference for cartilage (Haskell et al., 2008). In addition, species of the Coleoptera order families are able to respond to soil changes (Parry et al., 2016). In studies carried out with carcasses, the Coleoptera and Formicidae families were found in advanced stages of decomposition (Cruise et al., 2018; Tembe \& Mukaratirwa, 2021; Zeariya \& Kabadaia, 2019). In this experiment, the presence of beetle families such as Cerambycidae, Chrysomelidae, Nitidulidae, Noteridae, and Dermestidae was mainly observed in the final stages.

Figure 4. Drying of rodent carcasses.

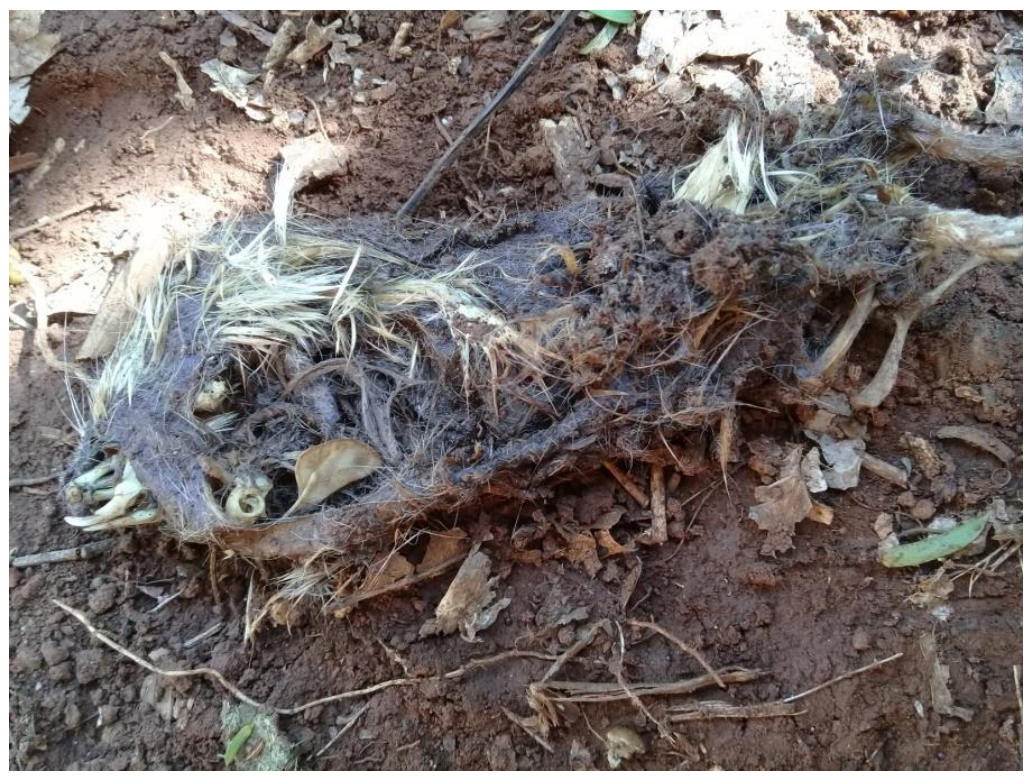

Source: author. 


\section{Conclusion}

Finally, we can conclude that the temperature and moisture of the soil were the main drivers of carcass decomposition over areas and periods. We also found that insect abundance is more important than insect richness to accelerating carcass decomposition. We also observed that buried carcasses in soil decompose more slowly due to the physical barrier caused by the soil. Most taxon indicators (Vespidae, Sarcophagidae, Muscidae, and Calliphoridae) declined over time, except Armadillidiidae, probably to use the carcasses as a refuge against dissection. Lastly, Coleoptera and Formicidae colonize the carcasses in the final stages of decomposition due to the facility of cartilage use. This abundance peak of insect families can serve as the baseline data for investigation and help to determine Post Mortem intervals on Neotropical Subtropical systems.

During the decomposition process, it is also important to take into account the influence of dipteran larvae on the carcasses, as they produce metabolic heat. This heat can be due to the increase in temperature caused by the aggregation and movement of larvae. Therefore, it would be interesting to measure the temperature of the larvae in the carcasses, using a thermometer, to better understand how the decomposition process takes place inside the carcass.

\section{Acknowledgments}

The authors thank Unochapecó for the availability of the Unochapeco laboratories use and for the undergraduate course in Biological Sciences of Unochapeco.

\section{References}

Al-Mekhlafi, F. A., Alajmi, R. A., Almusawi, Z., Mohammed Abd Al GAlil, F., Kaur, P., Al-Wadaan, M., \& Al-Khalifa, M. S. (2020). A study of insect succession of forensic importance: Dipteran flies (diptera) in two different habitats of small rodents in Riyadh City, Saudi Arabia. Journal of King Saud University - Science, 32(7), 3111-3118. https://doi.org/10.1016/j.jksus.2020.08.022

Alvim, E. A. C. C., Medeiros, A.O., Rezende, R. S., \& Gonçalves, J. F. Jr. (2020). Small leaf breakdown in a Savannah headwater stream. Limnologica, 51(1), 131-138. https://doi.org/10.1016/j.limno.2014.10.005

Andrade-Herrera, K. N., Mello-Patiu, C. A., Núñez-Vázquez, C., \& Estrella, E. (2020). Flesh Flies (Diptera: Sarcophagidae) Attracted to a Snake Carcass (Boa constrictor) in Yucatan Peninsula, Mexico. Journal of Medical Entomology, 57(6), 2011-2015. https://doi.org/10.1093/jme/tjaa115

Baker, M. E., \& King, R. S. (2010). A new method for detecting and interpreting biodiversity and ecological community thresholds. Methods in Ecology and Evolution, 1(1), 25-37. https://doi.org/10.1111/j.2041-210X.2009.00007.x

Baker, M. E., \& King, R. S. (2013). Of TITAN and straw men: An appeal for greater understanding of community data. Freshwater Science, 32(2), 489-506. https://doi.org/10.1899/12-142.1

Bornemissza, G. (1957). An analysis of Arthropod succession in Carrion and the effect of its decomposiion on the soil fauna. Australian Journal of Zoology, $5(1), 1-12$.

Byrd, J. H., \& Castner, J. L. (2001). Insect of forensic importance. Forensic entomology: The utility of arthropods in legal investigations. CRC Press,

Carvalho, C. J. B. de, \& Mello-Patiu, C. A. de. (2008). Key to the adults of the most common forensic species of Diptera in South America. Revista Brasileira de Entomologia, 52(3), 390-406. https://doi.org/10.1590/S0085-56262008000300012

Crawley, M. J. (2007). The R Book. John Wiley \& Sons Ltd.

Cruise, A., Watson, D. W., \& Schal, C. (2018). Ecological succession of adult necrophilous insects on neonate Sus scrofa domesticus in central North Carolina. PLOS ONE, 13(4), e0195785. https://doi.org/10.1371/journal.pone.0195785

Cruz, T. M., \& Vasconcelos, S. D. (2006). Entomofauna de solo associada à decomposição de suíno em um fragmento de Mata Atlântica de Pernambuco, Brasil. 14(2), 10.

De Frenne, P., Zellweger, F., Rodríguez-Sánchez, F., Scheffers, B. R., Hylander, K., Luoto, M., Vellend, M., Verheyen, K., \& Lenoir, J. (2019). Global buffering of temperatures under forest canopies. Nature Ecology \& Evolution, 3(5), 744-749. https://doi.org/10.1038/s41559-019-0842-1

Dufrêne, M., \& Legendre, P. (1997). Species assemblages and indicator species: The need for a flexible asymmetrical approach. Ecological Monographs, 67(3), 345-366. https://doi.org/10.1890/0012-9615(1997)067[0345:SAAIST]2.0.CO;2

Feng, A. Y. T., \& Himsworth, C. G. (2014). The secret life of the city rat: A review of the ecology of urban Norway and black rats (Rattus norvegicus and Rattus rattus). Urban Ecosystems, 17(1), 149-162. https://doi.org/10.1007/s11252-013-0305-4

Haskell, N. H., Williams, R. E., Catts, D., Adkins, J., \& Haskell, C. (2008). Entomology and death: A procedural guide. East Park Printing. 
Herdina, A., Bitencourt, G., Mare, R. D., \& Barbosa, B. C. (2016). Polybia (Myrapetra) scutellaris (Hymenoptera: Vespidae) foraging on flies at carcasses of Rattus norvegicus (Rodentia: Muridae). Sociobiology, 63(1), 728-730. https://doi.org/10.13102/sociobiology.v63i1.937

Higley, L. G., \& Huntington, T. E. (2009). Forensic Entomology: An Introduction. Journal of Medical Entomology, 46(5), 1244-1244. https://doi.org/10.1603/033.046.0538

Ito, M. (2021). Frequency of carcass burial in animal burrows for reproduction by Nicrophorus concolor (Coleoptera: Silphidae). Journal of Ethology, 39(1), 141-144. https://doi.org/10.1007/s10164-020-00678-8

Jales, J. T., Barbosa, T. de M., dos Santos, L. C., Rachetti, V. de P. S., \& Gama, R. A. (2020). Carrion decomposition and assemblage of necrophagous dipterans associated with Terbufos (Organophosphate) intoxicated rat carcasses. Acta Tropica, 212, 105652. https://doi.org/10.1016/j.actatropica.2020.105652

King, R. S., Baker, M. E., Kazyak, P. F., \& Weller, D. E. (2011). How novel is too novel? Stream community thresholds at exceptionally low levels of catchment urbanization. Ecological Applications, 21(5), 1659-1678. https://doi.org/10.1890/10-1357.1

King, R. S., \& Richardson, C. J. (2003). Integrating Bioassessment and Ecological Risk Assessment: An Approach to Developing Numerical Water-Quality Criteria. Environmental Management, 31(6), 795-809. https://doi.org/10.1007/s00267-002-0036-4

Kotzé, Z., Villet, M. H., \& Weldon, C. W. (2016). Heat accumulation and development rate of massed maggots of the sheep blowfly, Lucilia cuprina (Diptera: Calliphoridae). Journal of Insect Physiology, 95, 98-104. https://doi.org/10.1016/j.jinsphys.2016.09.009

Kutcherov, D., Lopatina, E. B., \& Yermakov, S. (2019). Effects of Temperature and Photoperiod on the Immature Development in Cassida rubiginosa Müll. and C. stigmatica Sffr. (Coleoptera: Chrysomelidae). Scientific Reports, 9(1), 10047. https://doi.org/10.1038/s41598-019-46421-3

Maestri, R., Galiano, D., Kubiak, B. B., \& Marinho, J. R. (2014). Diversity of small land mammals in a subtropical Atlantic forest in the western region of the state of Santa Catarina, southern Brazil. Biota Neotropica, 14(4). https://doi.org/10.1590/1676-06032014012914

Maestri, R., Galiano, D., Kubiak, B. B., \& Marinho, J. R. (2014). Diversity of small land mammals in a subtropical Atlantic forest in the western region of the state of Santa Catarina, southern Brazil. Biota Neotropica, 14(4). https://doi.org/10.1590/1676-06032014012914

Medeiros, A. O., Callisto, M., Graça, M. A. S., Ferreira, V., Rosa, C. A., França, J., Eller, A., Rezende, R. S., \& Gonçalves, J. F. Jr., (2015). Microbial colonization and litter decomposition in a Cerrado stream is limited by low dissolved nutrient concentration. Limnetica, 34(2), 283-292. https://doi.org/ 10.23818/limn.34.22

Moretti, T. de C., \& Ribeiro, O. B. (2006). Cephalotes clypeatus Fabricius (Hymenoptera: Formicidae): hábitos de nidificação e ocorrência em carcaça animal. Neotropical Entomology, 35(3), 412-415. https://doi.org/10.1590/S1519-566X2006000300019

Moskowitz, B. M., Jackson, M., \& Chandler, V. (2015). Geophysical Properties of the Near-Surface Earth: Magnetic Properties. In G. Schubert (Ed.), Treatise on Geophysics (Second Edition) (pp. 139-174). Elsevier. https://doi.org/10.1016/B978-0-444-53802-4.00191-3

Na, M., \& Pt, J. (2013). Forensic Entomology in Malaysia: A Review. Malaysian Journal of Forensic Sciences, 4(1), 7.

Navarro, F. K. S. P., Rezende, R. S., \& Gonçalves, J. F. Jr., (2013). Experimental assessment of temperature increase and presence of predator carcass changing the response of invertebrate shredders. Biota Neotropica, 13(4), 28-33. https://doi.org/10.1590/S1676-06032013000400002

Oliveira-Costa, J. (2013). Insetos “Peritos”- A Entomologia Forense no Brasil. Millennium.

Ota, Y., Masuda, T., Araki, K., \& Yamaguchi, M. (2019). A mobile multipyranometer array for the assessment of solar irradiance incident on a photovoltaicpowered vehicle. Solar Energy, 184, 84-90. https://doi.org/10.1016/j.solener.2019.03.084

Parry, N. J., Mansell, M. W., \& Weldon, C. W. (2016). Seasonal, Locality, and Habitat Variation in Assemblages of Carrion-Associated Diptera in Gauteng Province, South Africa. Journal of Medical Entomology, 53(6), 1322-1329. https://doi.org/10.1093/jme/tjw104

Probst, C., Gethmann, J., Amendt, J., Lutz, L., Teifke, J. P., \& Conraths, F. J. (2020). Estimating the Postmortem Interval of Wild Boar Carcasses. Veterinary Sciences, 7(1), 6. https://doi.org/10.3390/vetsci7010006

Pujol-Luz, J. R., Marques, H., Ururahy-Rodrigues, A., Rafael, J. A., Santana, F. H. A., Arantes, L. C., \& Constantino, R. (2006). A Forensic Entomology Case from the Amazon Rain Forest of Brazil. Journal of Forensic Sciences, 51(5), 1151-1153. https://doi.org/10.1111/j.1556-4029.2006.00217.x

Quintão, J. M. B., Rezende, R. S. \& Gonçalves, J. F. Jr., (2013). Microbial effects in leaf breakdown in tropical reservoirs of different trophic status. Freshwater Science 32(1), 933-950. https://doi.org/10.1899/12-112.1

Rabinowitz, A., \& Nottingham, B. G. J. (1989). Mammal species richness and relative abundance of small mammals in a subtropical wet forest of Central America. 53(2), 217-226. https://doi.org/10.1515/mamm.1989.53.2.217

Rezende, R. S., Medeiros, A. O., Gonçalves, J. F., Feio, M. J., Pereira Gusmão, E., de Andrade Gomes, V. Â., Calor, A., \& Almeida, J. dos S. D. (2019). Patterns of litter inputs, hyphomycetes and invertebrates in a Brazilian savanna stream: A process of degradative succession. Journal of Tropical Ecology, 35(6), 297-307. https://doi.org/10.1017/S0266467419000269

Rezende, R. S., Bernardi, J. P., Gomes, E. S., Martins, R. T., Hamada, N., \& Gonçalves, J. F. (2021). Effects of Phylloicus case removal on consumption of leaf litter from two Neotropical biomes (Amazon rainforest and Cerrado savanna). Limnology, 22(1), 35-42. https://doi.org/10.1007/s10201-020-00628-w

Rezende, R. S., Santos, A. M., Medeiros, A. O., \& Gonçalves Jr., J. F. (2017). Temporal leaf litter breakdown in a tropical riparian forest with an open canopy. Limnetica, 36, 445-459. https://doi.org/10.23818/limn.36.14 
Research, Society and Development, v. 11, n. 1, e7511124558, 2022

(CC BY 4.0) | ISSN 2525-3409 | DOI: http://dx.doi.org/10.33448/rsd-v11i1.24558

Richards, C. S., Williams, K. A., \& Villet, M. H. (2009). Predicting Geographic Distribution of Seven Forensically Significant Blowfly Species (Diptera: Calliphoridae) in South Africa. African Entomology, 17(2), 170-182. https://doi.org/10.4001/003.017.0207

Rodríguez, J. N., \& Liria, J. (2017). Seasonal abundance in necrophagous Diptera and Coleoptera from northern Venezuela. Tropical Biomedicine, 34(2), 315323.

Sfenthourakis, S., \& Hornung, E. (2018). Isopod distribution and climate change. ZooKeys, 801, 25-61. https://doi.org/10.3897/zookeys.801.23533

Souza, A. M., \& Linhares, A. X. (1997). Diptera and Coleoptera of potential forensic importance in southeastern Brazil: Relative abundance and seasonality. Medical and Veterinary Entomology, 1(11), 8-12. https://doi.org/10.1111/j.1365-2915.1997.tb00284.x

Tedesco, M. J., Gianello, C., Bissani, C. A., Bohmen, H., \& Volkweiss, S. J. (1995). Analises de solo, plantas e outros materiais (2nd ed.). Porto Alegre: Departamento de solos da UFRGS.

Tembe, D., \& Mukaratirwa, S. (2021). Insect Succession and Decomposition Pattern on Pig Carrion During Warm and Cold Seasons in Kwazulu-Natal Province of South Africa. Journal of Medical Entomology, tjab099. https://doi.org/10.1093/jme/tjab099

Terborgh, J., Losos, E., Riley, M. P., \& Riley, M. B. (1993). Predation by vertebrates and invertebrates on the seeds of five canopy tree species of an Amazonian forest. In T. H. Fleming \& A. Estrada (Eds.), Frugivory and seed dispersal: Ecological and evolutionary aspects (pp. 375-386). Springer Netherlands. https://doi.org/10.1007/978-94-011-1749-4_26

Trivia, A. L., \& de Carvalho Pinto, C. J. (2018). Analysis of the Effect of Cyclophosphamide and Methotrexate on Chrysomya megacephala (Diptera: Calliphoridae),. Journal of Forensic Sciences, 63(5), 1413-1418. https://doi.org/10.1111/1556-4029.13740

von Hoermann, C., Lackner, T., Sommer, D., Heurich, M., Benbow, M. E., \& Müller, J. (2021). Carcasses at Fixed Locations Host a Higher Diversity of Necrophilous Beetles. Insects, 12(5), 412. https://doi.org/10.3390/insects12050412

Wang, Y., Wang, Y., Wang, M., Xu, W., Zhang, Y., \& Wang, J. (2021). Forensic Entomology in China and Its Challenges. Insects, 12(3), 230. https://doi.org/10.3390/insects12030230

Wolff, M., Uribe, A., Ortiz, A., \& Duque, P. (2001). A preliminary study of forensic entomology in Medellín, Colombia. Forensic Entomology, 120(1), 53-59. https://doi.org/10.1016/S0379-0738(01)00422-4

Zeariya, M., \& Kabadaia, M. (2019). The Abundance of Forensic Insects on Dog and Rabbit Carcasses in Different Habitats and Developmental Stages of Chrysomya albiceps as a Forensic Indicator. Egyptian Academic Journal of Biological Sciences, E. Medical Entomology \& Parasitology, 11(1), 41-49. https://doi.org/10.21608/eajbse.2019.38885 